\title{
Kristendommens aktualitet som viljen til sandhed
}

\author{
- og et beskedent forsvar for en radikal korsteologi
}

\author{
Ph.d.-stipendiat, cand.theol. Mads Peter Karlsen
}

I skal lære sandheden at kende og sandheden skal gøre jer frie. Johannesevangeliet 8,32 .

\begin{abstract}
This article discusses the question of the influence and potential of Christianity in contemporary secularized culture. I take as my starting point the twofold thesis that 'God is dead' and 'Christianity survived the death of God'. In section 1 and 2 I demonstrate how Friedrich Nietzsche and Michel Foucault have elaborated this thesis in a somewhat similar manner by criticising the ideological workings of what in the words of Nietzsche could be called the Christian 'will to truth'. In section 3 I argue that Slavoj Žižek's recent engagement with theology allow for another reading of the Christian truth-seeking, which in contrast brings out a potential for a critique of ideology. The difference between these two readings can be summarized as two interpretations of the famous words in The Gospel of John, "you will know the truth, and the truth will set you free." Thus, Christianity does not only entail the suppressive danger of an obligation to tell the truth about oneself at any prize, it also offers the liberating prospective in being true to the manifestation of the death of God on the cross.
\end{abstract}

Key words: The death of God - will to truth - Friedrich Nietzsche confession - psychoanalysis - Michel Foucault - a suffering God - theology of the cross - Slavoj Žižek.

På en af de sidste sider af sin bog Moralens oprindelse fra 1887 stiller Friedrich Nietzsche følgende spørgsmål: "Strengt taget: Hvad har egentlig sejret over den kristne gud?" Nietzsche svarer selv med et citat fra et af sine tidligere værker, Den muntre videnskab fra 1882; "Selve den kristne moralitet, det stadig strengere begreb om sandfærdighed, den kristne samvittigheds skriftefader-raffinement overført og sublimeret til videnskabelig samvittighed, til integritet for enhver 
pris." Lad mig forsøge at udfolde lidt nærmere, hvad Nietzsche mener med dette spørgsmål og med sit svar.

\section{Nietzsche: Hvad har sejret over den kristne Gud?}

I spørgsmålet “Hvad har egentlig sejret over den kristne gud?” har Nietzsche, som man kan se, kursiveret 'hvad' og 'sejret'. Hvorfor? Det banale og indlysende korrekte svar er naturligvis, at det har han gjort, fordi han vil markere en tvetydighed ved netop disse to ord. Hvori denne tvetydighed består, bliver tydeligt i hans efterfølgende svar. Hvad er det nemlig, der har sejret over den kristne Gud? Det har den kristne moralitet, hvilket vil sige 'det stadig strengere begreb om sandfærdighed'. Det, Nietzsche påpeger, er med andre ord det underfundige forhold, at kristendommen - eller noget ved kristendommen - har sejret over kristendommen selv. Ordet sejret får således også en noget, ja tvetydig, betydning. Som oftest taler man jo om, at der er noget, som har sejret over noget andet, men her er der altså tale om, at noget, kristendommen, har sejret over sig selv. Der ligger imidlertid også en anden tvetydighed i ordet sejret her. Når man har sejret over noget eller nogen betyder det normalt også, at man har overvundet det, som man sejret over. Vi kender det fra, når man for eksempel siger: "Hun sejrede til sidst over sin sygdom." Men her er der ikke blot tale om, at kristendommen er blevet 'overvundet'. Den er også, eller måske snarere, blevet 'overført' og 'ophøjet' (sublimeret).

Det, jeg mener, Nietzsche siger her i denne passage, er kort sagt følgende: Det kan godt være, at den kristne Gud er død, ja, at vi endda har slået ham ihjel, hvad Nietzsche jo er berømt for at have erklæret, ${ }^{2}$ men det betyder ikke, at kristendommen er overvundet, måske endda tværtimod. Måske virker kristendommen endnu mere effektivt ind på os, netop fordi vi tror, at den er overvundet. Man kan sige, at Sigmund Freud er inden på noget tilsvarende, når han i sine religionskritiske analyser af myten om mordet på Ur-faderen i Totem og tabu påpeger, at faderen ikke mister sin magt over sønnerne, da de dræber ham, men at han netop præcis i kraft af sin død ender med at vende tilbage i en langt mere magtfuld guddommelig udgave. ${ }^{3}$ I forlængelse

1. Friedrich Nietzsche, Moralens oprindelse (Frederiksberg: DET lille FORLAG 1998), 175.

2. Friedrich Nietzsche, Den muntre videnskab (Frederiksberg: DET lille FORLAG 1997), 125.

3. Sigmund Freud, Totem og tabu: nogle overensstemmelser mellem sjalelivet hos de vilde og hos neurotikerne; En djevleneurose fra det 17. ärhundrede; En illusions fremtid (København: Hans Reitzels Forlag 1983), 116. 
heraf har den franske psykoanalytiker Jacques Lacan bemærket, at "[...] ateismens virkelige sætning er ikke Gud er død [...] ateismens virkelige sætning er Gud er ubevidst." ${ }^{4}$ Det vil sige, at først når man har indset, at Gud fortsat huserer efter sin død, bliver ateismen mulig. Som den slovenske filosof og psykoanalytiker Slavoj Žižek foreslår i sin introduktion til Lacan, så lader Lacans pointe sig måske $\mathrm{i}$ virkeligheden bedst illustrere gennem den følgende vittighed: En mand bliver indlagt på en sindssygeanstalt, fordi han tror, at han er et kornfrø. Lægen på sindssygeanstalten får til sidst manden overbevidst om, at han ikke er et kornfrø, men et menneske, hvorefter manden får lov til at forlade sindssygeanstalten. Men knap nok er manden trådt ud af døren, før han vender tilbage til sindssygeanstalten, bævende og rystende af skræk. "Der er en høne uden for døren, som vil spise mig", siger han til lægen. "Men kære ven," siger lægen, "du ved jo udmærket godt, at du ikke er et kornfrø, men et menneske". "Ja selvfølgelig", siger manden, "jeg ved det godt, men ved hønen det også?”' Først når man har indset, at 'Gud er ubevidst', at Gud ikke bare er en subjektiv illusion, der kan ophæves ved blot at få at vide eller at proklamere, at han ikke eksisterer, kan man ifølge Žižek forholde sig til hele det netværk af handlinger, sprog og sociale relationer, hvori dette ubevidste sætter sig igennem bag om ryggen på en, og således nærme sig en genuin ateistisk position, hvor det ikke alene er mig, men også Gud selv, der ved, at han er død. ${ }^{6}$

Tilbage til Nietzsche. Nietzsche siger ikke kun, at kristendommen stadig gør sig gældende. Han siger også noget interessant om, i hvilken skikkelse den gør sig gældende. Nemlig som den kristne moralitet; mere præcis den kristne moralitet i form af et stadig strengere begreb om sandfærdighed. Denne kompromisløse sandfærdighedsmoralitet, som bliver tilbage, når kristendommen har sejret over sig selv, kalder Nietzsche også 'viljen til sandhed'. Nærmere bestemt implicerer denne vilje til sandhed, som ifølge Nietzsche $(1998,174)$ udgør kernen i kristendommen, en intim forbindelse mellem det allermest ophøjede, Gud, og så sandheden, eller med Johannesevangeliets famøse ord: "Jeg er vejen og sandheden og livet; ingen kommer til Faderen uden

4. Jacques Lacan, Psykoanalysens fire grundbegreber - seminar XI (København: Politisk Revy 2004), 55.

5. Slavoj Žižek, How to read Lacan (New York: W.W. Norton og Company 2007), 93.

6. Man kunne spørge, om ikke den kristne Guds råb på korset: "Min Gud, min Gud, hvorfor har du forladt mig", netop er et udtryk for en sådan Gud, der har indset sin egen (forestående) død? Eller med G.K. Chestertons (1874-1936) ord, et udtryk for, at "[...] God seem for an instant to be an atheist.", Gilbert K. Chesterton, Orthodoxy (San Francisco: Ignatius 1995), 145. 
ved mig" (Joh 14,6). Det er denne 'kristne' forbindelse mellem det allermest ophøjede og sandheden, som Nietzsche hævder lever videre, ja måske endda intensiveres, selv efter at kristendommen for længst synes at have udspillet sin rolle. Nietzsche formuler det selv på den følgende måde: “Også vi erkendende i dag, vi gudsløse og antimetafysikere, også vi tager endnu vor ild fra den brand, en årtusind gammel tro har antændt, den kristentro, der også var Platons, at Gud er sandheden, at sandheden er guddommelig..." (Nietzsche 1998, 166). ${ }^{7}$ Så anderledes sagt, hvis vi stadig i dag, længe efter at vi gladelig har erklæret den kristne Gud for død, er under kristendommens indflydelse, så er det i form af en vilje til sandhed og en vilje til sandhed for enhver pris.

Da Nietzsche skulle identificere denne 'overførte og sublimerede' vilje til sandhed i sin samtid i slutningen af det 19. århundrede, pegede han, som antydet i citatet ovenfor, især på den moderne videnskab; ikke kun den i tiden så feterede naturvidenskab, men også eksempelvis historievidenskaben, der for alvor tog form af en egentlig videnskab netop i denne periode. Således kritiserer han i sit lille skrift Historiens nytte fra 1874 historieskrivning for at besidde en 'videnskabelig samvittighed', en vilje til sandhed, der er så stærk, at den i stedet for at fremme, faktisk risikerer at ende med at hæmme det liv, som den egentlig var sat i verden for at gøre os klogere på. Som modtræk til sin samtids 'historiske syge' stiller Nietzsche den betingelse til historieskrivningen, at "Kun for så vidt historien tjener livet, vil vi tjene den."8 Opsummerende kan man lidt forsimplet sige, at det spørgsmål, som Nietzsche stillede på de sidste sider af Moralens oprindelse, var det følgende: I hvilke ritualer, praksisser, diskurser og sociale relationer lever troen på Gud som troen på Sandheden videre? Og det svar, som han gav, var altså, at det særligt er i vores videnskabelige praksisser, at troen på Gud er overleveret.

7. Når Nietzsche her skriver, at troen på, at Gud er sandheden, at sandheden er guddommelig, 'også var Platons', så er hans pointe naturligvis ikke, at kristendommen rastløst kan reduceres til platonisme (han påpeger tværtimod netop, at "[...] kristendom er platonisme for 'folket"), men at den kun lader sig forstå på baggrund af platonismen, ligesom viljen til sandhed i dens moderne sekulære skikkelse kun lader sig forstå på baggrund af kristendommen. Friedrich Nietzsche, Hinsides godt og ondt (Frederiksberg: DET lille FORLAG 2002), 18. Min kursivering.

8. Friedrich Nietzsche, Historiens nytte (København: Gyldendal 1996), 36. 


\section{Foucault: Kristendommens skriftefader-raffinement}

Hvis man vil forsøge at gå i Nietzsches fodspor og spørge til, hvordan kristendommen i skikkelse af 'viljen til sandhed for enhver pris' kommer til udtryk i vores egen samtid, kan man få god hjælp af den franske filosof og idéhistoriker Michel Foucault. Ikke fordi Foucault var specielt interesseret i spørgsmålet om kristendommens aktualitet, men fordi han ligesom Nietzsche var dybt optaget af at diagnosticere samtidens moral ved at optrevle og undersøge dens historiske slægtskabslinjer, og derfor alligevel endte med at sige noget væsentligt om dette spørgsmål. For ligesom for Nietzsche er det også tydeligt for Foucault, at samtidens moral har dybe rødder i kristendommen. Og noget kunne tyde på, at Foucault, der var velbevandret i Nietzsches forfatterskab, i sine undersøgelser af vores samtidsmoral har hæftet sig særligt ved en bestemt del af den ovenfor gengivede passage fra Moralens oprindelse, nemlig at den sandfærdighedsmoralitet eller vilje til sandhed, der ifølge Nietzsche kendetegner kristendommens selvoverleverede kerne, er en overført og sublimeret udgave af 'den kristne samvittigheds skriftefader-raffinement'. I hvert fald kan man i Foucaults bog - med den sigende titel Viljen til viden fra 1976 - læse følgende passage, som fortjener et længere citat:

[...] bekendelsen [er], ved siden af forsikringer givet af traditionens autoritet, ved siden af vidneudsagnene, men også ved siden af videnskabelige iagttagelses- og bevismetoder, blevet en af den vestlige verdens højest vurderede teknikker for produktionen af sandhed. Vi er blevet et $\mathrm{i}$ høj grad bekendende samfund. Bekendelsens virkninger er vidt udbredte: indenfor retsplejen, medicinen, pædagogikken, i familierne, kærlighedsforholdene, under de mest dagligdags omstændigheder og højtideligste ritualer: man bekender sine forbrydelser og sine synder, man bekender sine tanker og sine begær, man bekender sin fortid og sine drømme, man bekender sin barndom, man bekender sine sygdomme og elendigheder $[\ldots]$ man bekender offentligt og privat, til sine forældre, til sine opdragere, til sin læge, til dem man elsker, til sig selv gør man, af lyst og af nød, endelig de kendelser, der umuligt kan gøres overfor andre, ja man gør endog disse bekendelser til bøger. ${ }^{9}$

Alle disse mange forskellige bekendelsesformer, som gør sig gældende overalt i det moderne samfund, har ifølge Foucault deres rod i den kristne bekendelse, der gennem århundrederne er blevet udbredt til (og tilpasset) en lang række sammenhænge hinsides de kirkelige insti-

9. Michel Foucault, Viljen til viden: Seksualitetens historie bind I (Frederiksberg: DET lille FORLAG 1998), 66-67. 
tutioner, hvori den blev til (Foucault 1998, 71). Den væsentlige pointe, som jeg mener kommer til udtryk, når man læser dette Foucault-citat i forlængelse af det indledende citat af Nietzsche, er således, at hvis vi vil sige noget om kristendommens aktualitet i dens sublimerede form som viljen til sandhed, så kan vi måske bedst gøre det ved nærmere at undersøge disse bekendelsespraksisser, som Foucault påpeger spiller en så afgørende rolle i de moderne vestlige samfund.

Foucault selv fokuserede imidlertid især på en bestemt samtidig bekendelsespraksis, nemlig psykoanalysen. ${ }^{10}$ Det skyldes, at psykoanalysen, og særligt dens forestilling om at man gennem samtale kan afdække sit sande jeg, er blevet udbredt til en lang række sammenhænge, hvori vi netop gennem forskellige varianter af samtaleterapeutiske redskaber inciteres til at fremsætte og påtage os bestemte sandheder om os selv. Det kunne fx være elevsamtaler, rygestopsamtaler, klientudredningssamtaler og medarbejderudviklingssamtaler. I disse, og mange andre lignende, mere eller mindre formaliserede samtalesituationer, inviteres eller opfordres vi ustandseligt til at fremsige sandheden om os selv: Hvordan kan det være, at vi ikke kan sidde stille i matematiktimerne? Hvorfor tror vi, at vi ikke kan holde op med ryge? Hvilke årsager mener vi selv, at der er til at vi bliver stressede? Men hermed forpligtes vi samtidig også på denne sandhed, som vi udsiger om os selv. På denne måde etableres der en subtil magtrelation mellem den, der forpligter sig gennem den sandhed, som han eller hun udsiger om sig selv, og så den, der opfordrer til denne sandhedsudsigelse. I sin analyse af den kristne bekendelse i Viljen til viden beskriver Foucault det på følgende måde:

Dens [bekendelsens] sandhed garanteres ikke af mesterens fjerne autoritet og heller ikke af den tradition, han viderefører; men af det bånd [...], der består mellem den, der taler, og det han taler om. Til gengæld befinder dominationsinstansen sig ikke hos den, der taler [...], men hos den, der lytter og tier; ikke hos den, der er bekendt med og nævner svaret,

10. Selvom Freuds navn naturligvis ofte optræder i Foucaults kritiske behandling af psykoanalysen, så synes målet for denne behandling først og fremmest at være den amerikaniserede og populariserede udgave af psykoanalysen, den såkaldte 'ego-psykologi'. Foucault priser derimod ved adskillige lejligheder Freud for $\mathrm{fx}$ for hans opposition til fascismen (Foucault 1998, 155-56), ligesom han fremhæver Freuds måske mest freudianske efterfølger, Jacques Lacan, for at have været den eneste foruden Martin Heidegger, som i det 20. århundrede har stillet spørgsmålet om sandheden, (Michel Foucault, The Hermeneutics of the Subject: Lectures at the Collège de France 1981-1982, (New York: Picador), 189. For en grundig og kritisk gennemgang af Foucault komplekse forhold til psykoanalysen, se Joel Whitebook, "Against Interiority: Foucault's struggle with psychoanalysis", The Cambridge Companion to Foucault, red. Gary Gutting (Cambridge: Cambridge University Press 2005), 312-347. 
men hos den, der spørger og ikke formodes at vide besked. Og denne sandhedstale virker faktisk ikke hos ham, der modtager den, men hos ham, den aftvinges (Foucault 1998, 70).

Det er denne magtfulde forbindelse mellem tale, sandhed og forpligtigelse, der for alvor har Foucaults interesse, og som han mener udgør den 'kerne', som vores moderne samtalepraksisser har arvet fra den kristne bekendelse.

Foucault har imidlertid også et skarpt blik for et andet bemærkelsesværdigt træk ved den magtrelation, som bekendelsen etablerer, nemlig at den meget sjældent er knyttet til nogen form for tvang, men tværtimod stort set altid iværksættes ganske frivilligt. Hvorfor? Fordi, og her nærmer Foucault sig for alvor Nietzsches idé om viljen til sandhed, bekendelsen ikke alene forudsætter, men med tiden også er blevet en medvirkende faktor til det, man kunne kalde 'sandhedsudsigelsens 'internalisering' og 'naturalisering'. Foucault formulerer det på den følgende måde:

Forpligtelsen til tilståelse [...] er så fast indpodet i os, at vi ikke længere kan opfatte den som udslag af en magt, som tvinger os, det forekommer os tværtimod, at sandheden i vort allerhemmeligste ikke "søger" andet end at komme for dagen, og at hvis sandheden ikke kommer [for dagen], er det fordi en tvang holder den tilbage [...], og at den ikke vil kunne artikuleres førend en slags frigørelse endelig indtræffer. Bekendelsen frigør, magten bringer til tavshed (Foucault 1998, 67).

Pligten til sandhedsudsigelse fremstår således ikke længere som noget udefra pålagt, men i stedet som noget indefra kommende, netop som en vilje til sandhed, endog en vilje til sandhed, der sætter os fri fra magten. Det diabolske ved den kristne bekendelse, og dens moderne afløsere, er således, at det er i selve det øjeblik, hvor man opfordres til - gennem fremsigelsen af sandheden om sig selv - at frigøre sig selv, at magtudøvelsen er mest effektiv. Som for eksempel når vi konstant af alverdens terapeuter, rådgivere og coaches opfordres til at frigøre os fra den herskende moral eller den politiske korrekthed og åbent vedkende os (og realisere) vores inderste fantasier og begær.

Det er disse i samtiden efterhånden allestedsnærværende bekendelses- eller samtalepraksisser, som Foucault indirekte har i sigtekornet, når han forsøger at problematisere psykoanalysen ved gennem sine historiske optrevlinger at fremvise dens prekære herkomst. Psykoanalysen har som bekendt traditionelt været i opposition til religion og hermed også til kristendommen. Det har den været først og fremmest på en meget direkte måde i form af dens religionskritik, som allerede Freud indledte i Totem og Tabu og En illusions fremtid, og som siden 
er blevet videreført af andre. Men psykoanalysen har også været i opposition til religion på en mere indirekte måde, nemlig i kraft af dens semividenskabelige status. Med udgangspunkt i denne oppositionelle baggrund forsøger Foucault i Viljen til viden at problematisere psykoanalysen ved at optegne en uventet og ubekvem slægtskabslinje mellem psykoanalyse og kristendom. Mere præcist mellem på den ene side psykoanalysens moderne semividenskabelige samtaleterapi, der ifølge Foucault hævder at have frigørelsen af et seksuelt subjekt gennem realiseringen af dets biologiske begær som sit formål, og på den anden side den førmoderne kristne bekendelse, som har til formål at hjælpe et syndigt subjekt med at opnå sjælens frelse gennem forsagelsen af dets kødelige begær. Lidt forsimplet sagt kan man sige, at Foucault her bruger et kritisk greb, hvor han ved hjælp af historien viser, hvordan psykoanalysen rummer en række elementer, som både i tid og rum stammer fra en sammenhæng, der betragtes som hørende til 'udenfor' psykoanalysen for hermed at problematisere dens egen og omgivelsernes opfattelse af den. ${ }^{11}$ Man kan også sige, at Foucault forsøger at problematisere psykoanalysen ved at fremvise, hvad man med Nietzsche kunne kalde dens pudenda origo, ${ }^{12}$ dens 'skammelige ophav', i den kristne religion, som den selv lægger afstand til. Hermed problematiserer Foucault naturligvis på sin vis også samtidig kristendommen, nemlig som en prekær arv, der fortsat sætter sig igennem i vores ellers angiveligt gennemsekulariserede samtid.

\section{3. Žižek: En sand Gud er en død Gud ...}

$\mathrm{Nu}$ var det selvsagt ikke alle, der blev lige begejstret for Foucaults fremstilling af psykoanalysen som et barn af kristendommen. En af dem, som reagerede stærkt imod den, var Lacans svigersøn og arvtager, den franske psykoanalytiker Jacques-Alain Miller. I en berømt rundbordsamtale fra 1977 diskuterede han sammen med flere andre, deriblandt en række filosoffer og historikere, Viljen til viden med Foucault. I denne samtale anklager Miller Foucault for at forsøge at udviske det brud i seksualitetens historie, som han mener, at Freud indstifter, og han afviser således, at der skulle kunne være tale om no-

11. Man kunne med den norske idéhistoriker Esben Schaanning kalder dette kritiske greb for 'idéhistorisk intervention'. For en videre uddybning se Esben Schaanning, Fortiden $i$ vaire hender - Foucault som vitenshåndtør Bind. I (Olso: Unipub forlag 2000), 5-32.

12. Friedrich Nietzsche, Nachlaß 1885-1887 i: (red.) G. Colli og M. Montinari Sämtliche Werke Band 12, Kritische Studienausgabe (München: Deutscher Taschenbuch Verlag, de Gruyter 1980), 160. 
gen form for kontinuitet mellem den kristne bekendelse eller kristendommen som sådan og psykoanalysen. ${ }^{13}$

I lighed med Miller afviser dennes nok mest berømte elev, nemlig tidligere nævnte Slavoj Žižek, ligeledes Foucaults parallel mellem den kristne bekendelse og psykoanalysen. ${ }^{14}$ Men i modsætning til sin lærermester så har Žižek intet problem med at bekræfte, at der skulle være andre forbindelseslinjer mellem psykoanalysen og kristendommen, ja, han ikke alene bekræfter, men understreger det eksplicit. ${ }^{15}$ Žižek henviser desuden til, at Freud selv har antydet et slægtskab mellem psykoanalysen og kristendommen, idet han i sin sidste bog, Manden Moses og Monoteisme, påpeger, at kristendommen med korsfæstelsen af Jesus røber jødedommens traumatiske hemmelighed, nemlig fadermordet. ${ }^{16}$ Med afsæt i denne pointe forsøger Žižek at udfolde Freuds antydning. Det gør han på følgende måde. Med Jesu råb fra korset, "min Gud, min Gud, hvorfor har du forladt mig!", vedstår kristendommen sig, ifølge Žižek, åbent noget, man i jødedommen har vidst siden Job, men som man ikke har villet acceptere og derfor ligesom Job selv - har holdt for sig selv, nemlig Guds magtesløshed. ${ }^{17}$

13. Michel Foucault, "Confessions of the flesh", Power/knowledge: Selected interviews \& other writings by Michel Foucault (New York: Pantheon 1980), 211. Se endvidere Jacques-Alain Miller, "Michel Foucault and Psychoanalysis", Michel Foucault-Philosopher, red. Timothy J. Armstrong (New York: Routledge 1992), 58-63.

14. Slavoj Žižek, The Indivisible Remainder: An Essay on Schelling and Related Matters (London: Verso 1996), 1-2.

15. Žižek påpeger for eksempel, at: "This is the lesson of both psychoanalysis and the Jewish-Christian tradition: the specific human vocation does not rely on the development of man's inherent potentials (on the awakening of the dormant spiritual forces OR of some genetic program); it is triggered by an external traumatic encounter, by the encounter of the Other's desire in its impenetrability", Slavoj Žižek, On Belief (London: Verso 2001), 47. Det er ikke anliggendet her at præstere en sammenlignende læsning af Foucault og Žižek, snarere en supplerende. For en sammenligning se Fabio Vighi og Heiko Feldner, Žižek: Beyond Foucault (New York: Palgrave Macmillan 2007).

16. Slavoj Žižek, The Fragile Absolute or, Why is the Christian Legacy worth fighting for? (London: Verso 2000), 97-98. Sigmund Freud, Der Mann Moses und die monotheistische Religion - Gesammelte Werke Bd. 16 (London: Imago Publishing Co., 1961), 196. Det er værd at bemærke, psykoanalysens traditionelle religionsfjendtlighed taget i betragtning, at Žižek langt fra er den eneste, der i de senere år har argumenteret for, at der eksisterer et nært slægtskab mellem den jødiskkristne religion og psykoanalysen. Se for eksempel: Eric L. Santner, On the Psychotheology of Everyday Life: Reflections on Freud and Rosenzweig (Chicago: University of Chicago Press 2001), Clayton Crokett, Interstices of The Sublime: Theology and Psychoanalytic Theory (New York: Fordham University Press 2007) og Marcus Pound, Theology, Psychoanalysis and Trauma (London: Veritas 2007).

17. Slavoj Žižek, The Puppet and the Dwarf: The Perverse Core of Christianity (Cambridge: MIT Press 2003), 126. 
Både jødedommen og kristendommen rummer således en indsigt $\mathrm{i}$ det særdeles 'dystre og frygtindgydende' forhold, at Gud slet ikke er nogen almægtig Gud, men i virkelighed en afmægtig Gud, der intet kan udrette overfor Jobs og Jesu lidelser. Men i modsætning til jødedommen hemmeligholder kristendommen imidlertid ikke denne afmægtighed. Tværtimod, den åbenbarer dette traumatiske forhold fuldt ud i kraft af Guds inkarnation og død på korset, hvorved åbenbaringen af dette forhold samtidig heller ikke længere forbeholdes en partikulær gruppe, men gøres universelt tilgængelig. Gennem denne læsning forsøger Žižek at eksplicere et nært slægtskab imellem kristendommens åbenbaring af en impotent Gud og psykoanalysens endemål som afsløring af den store Andens ikke-eksistens. Men han vender altså samtidig værdien af et sådant slægtskab på hovedet i forhold til Foucault, således det altså nu får et positivt snarere end et negativt fortegn (Žižek 2003, 169-171). I Žižeks udlægning udgør kristendommen, ligesom psykoanalysen, en konfrontation med den traumatiske, men også frigørende sandhed, at der ikke findes nogen absolut Grund, ingen stor Anden, ingen Fader. Eller som Žižek formulerer det i forhold til det, han anser som kristendommens altoverskyggende omdrejningspunkt, korsbegivenheden: "When Christ dies, what dies with him is the secret hope discernible in "Father, why hast thou forsaken me?": The hope that there is a father who has abandoned me." (Žižek 2003, 171). Teologisk talt er det, Žižek her plæderer for, altså en radikal korsteologi, hvor også Gud-faderen, som det også fremgår af citatet, dør sammen med sønnen på korset. Tilbage bliver 'alene' Helligånden i form af et fællesskab af troende. ${ }^{18} \mathrm{Gud}$ går således fra at være en transcendent substantiel entitet til at være et immanent 'virtuel' mellemværende, der alene eksisterer i kraft af de individers aktivitet, hvori han forudsættes:

What is sublated in the move from the Son to Holy Spirit is thus God himself: after the Crucifixion, the death of God incarnate, the universal God returns as a Spirit of the community of believers, i.e., he is the one who passes from being a transcendent substantial Reality to a virtual/ideal entity which exists only as the "presupposition" of acting individuals (Žižek og Milbank 2009, 61). ${ }^{19}$

Dette betyder ifølge Žižek også, at den kristne Gud er afmægtig i en anden forstand, nemlig i den forstand, at han intet kan gøre uden

18. Slavoj Žižek og John Milbank, The Monstrosity of Christ: Paradox or Dialectic? (Cambridge: MIT Press 2009), 29.

19. Denne udlægning af korsbegivenheden står, som Žižek også gør opmærksom på, i stor gæld til Hegel. Žižek er ganske udmærket klar over hvad der teologisk set 
mennesket, at han kun kan handle i og gennem mennesket, eller som Žižek siger det med et citat fra Paul Claudel: "Dieu ne peut rien sans nous [God can do nothing without us]" (Žižek og Milbank 2009, 60). Nu er Žižeks ærinde med kristendommen imidlertid ikke først og fremmest et teologisk men snarere et politisk ærinde, og i den henseende kan man sige, at hans pointe er, at selvom kristendommen utvivlsomt udgør et effektivt 'ideologisk apparat', for nu at parafrasere Louis Althusser, ${ }^{20}$ så rummer den samtidig i kraft denne korsteologisk åbenbaring af Guds død også et 'ideologikritisk' og frigørende potentiale. Nærmere bestemt er dette frigørende potentiale ved kristendommens traumatiske åbenbaring af Guds afmægtighed, at den muliggør det, Žižek beskriver som en 'frakobling' fra loven; eller rettere en frakobling fra lovens 'obskøne underside'. Med lovens 'obskøne underside' forstår Žižek en fortrængt, uofficiel tilskyndelse til overtrædelse, som ifølge Žižek altid følger med lovens offentligt anerkendte overside, dvs. de officielle udtalte eller nedskrevne forbud imod overtrædelse (Žižek 2000, 131). Loven indstifter nemlig med sin grænsedragning en forestilling om noget hinsides, der både undslipper og begrunder loven. Denne forestilling understøtter og opretholder på paradoksal vis loven præcis gennem sit incitament til overskridelse. Afkoblingen fra lovens obskøne underside består kort sagt i en distance til vores sociale forestillinger eller fantasier om noget sådant hinsides loven, der dækker over, at loven altså i sidste ende ikke er begrundet $\mathrm{i}$ andet end sig selv, og at den selv genererer dens overskridelser (Žižek 2003, 119). Denne distance finder Žižek blandt andet eksemplificeret $\mathrm{i}$ Jobs afvisning af sine tre teologiske venners forklaringer på sine lidelser, hvorved Job ifølge Žižek netop afslører, ikke at Gud er uretfærdig, men at han er afmægtig. Job fastholder på denne måde sine lidelsers meningsløshed. Og netop af den grund fremhæver Žižek ham som historiens første 'ideologikritiker' (Žižek 2003, 125).

Men også hos Paulus finder man ifølge Žižek denne jødisk-kristne frakoblende indstilling til lovens obskøne underside. Žižek forsøger blandt andet at belyse og uddybe dette forhold hos Paulus gennem en

står på spil i denne udlægning, nemlig den fulde identitet mellem den immanente og den økonomiske treenighed (Žižek og Milbank 2009, 253-254). Dette er ikke stedet at diskutere de nærmere konsekvenser af dette. I stedet vil jeg blot nøjes med at henvise til Regin Prenters diskussion af denne problematik hos Eberhard Jüngel, som Prenter netop klandrer for at være 'mere hegelsk end oldkirkelig i sin udlægning af treenighedstanken' (Regin Prenter, "Epilog”, Proslogion [af] Anselm af Canterbury oversat og udlagt som en indforelse i theologien Guds virkelighed [af] Regin Prenter (Aarhus: Udvalget for Konvent for Kirke og Theologi 1982), 144.

20. Louis Althusser, Ideologi og ideologiske statsapparater (Ålborg: Grus 1983). 
reference til den 'som-om' logik, der skitseres i første korinterbrev $(7: 29-31)$ :

[...] what the Pauline emergency suspends is not so much the explicit Law regulating our daily life, but, precisely, its obscene unwritten underside: when, in a series of as if prescriptions, Paul basically says: "obey the laws as if you are not obeying them", this means precisely that we should suspend the obscene libidinal investment in the law, the investment on account of which the Law generates/solicits its own transgression (Žižek 2003, 119).

Det jødisk-kristne forhold til loven er således kendetegnet ved en bevidsthed om, at lovens forbud indbefatter et incitament til overskridelse ('lovens obskøne underside'), og at enhver overskridelse altid samtidig bekræfter loven, således at ethvert forsøg på at frigøre sig fra loven ved at overskride den ikke underminerer, men blot bestyrker den. Det er netop denne selvbestyrkende dialektik imellem forbuddet imod og incitamentet til overskridelse, som Paulus gør opmærksom på i det berømte kapitel 7 i Romerbrevet (Žižek 2000, 99-100). ${ }^{21}$ Grunden til, at kristendommen er relevant for samtidens kritiske tænkning, er ifølge Žižek da også, at vi fortsat fastholdes i denne dialektik. I det moderne liberale kapitalistiske samfund har vi ganske rigtig gjort godt og grundigt op med autoriteterne. Kynisk bekendtgør vi, at der ingen faste værdier findes, vi respekterer ingen grænser og ligger ikke under for nogen norm. Tværtimod, vi ligefrem opfordres til konstant at kritisere autoriteterne, overskride grænserne og opsøge enhver mulig nydelse, men herved har man ifølge Žižek blot afskaffet lovens officielle overside, mens dens obskøne underside styrkes desto mere (Žižek 2007, 92). Vores opgør med autoriteterne og frigørelse fra forbuddene ender således med at medvirke til det stik modsatte.

Žižek ynder at illustrere dette tilsyneladende paradoks gennem den følgende anekdote, der viser kontrasten mellem to forskellige fadertyper. Man skal forestille sig en situation, som de fleste måske genkender fra barndommen: Et barn får besked på, at besøge sin bedstemor søndag eftermiddag, i stedet at lege med sine kammerater, og protesterer naturligvis. Den gammeldags autoritære faders besked til det modvillige barn ville være noget i retning af: "Jeg er ligeglad med, hvad du har lyst til. Du har bare at gøre din pligt og gå hen at besøge din bedstemor - og opfør dig ordentligt!" Den ikke-autoritær 'post-

21. Før Žižek har også Lacan bemærket, at Paulus blotlægger den mekanisme i Romerbrevet. Se Jacques Lacan, The Ethics of Psychoanalysis: The Seminar of Jacques Lacan: Book VII (New York: Routledge 2007), 102-103. 
moderne' faders besked ville derimod være noget i retning af: "Du ved udmærket godt, hvor meget din bedstemor holder af dig. Men jeg vil selvfølgelig ikke tvinge dig til at besøge hende, du skal kun gå derhen, hvis du selv virkelig vil det." I det første tilfælde er barnet, som Žižek $(2007,92)$ påpeger, faktisk ikke så dårlig stillet endda, for selvom det er tvunget til at gøre noget, det ikke ønsker, så har det stadigvæk sin indre frihed og evnen til at (måske senere) at gøre oprør mod den faderlige myndighed. Langt mere lumsk er imidlertid den ikke-autoritær 'postmoderne' faders besked. For som Žižek understreger:

Beneath the appearance of a free choice there is an even more oppressive demand than the one formulated by the traditional authoritarian father, namely an implicit injunction not only to visit the grandmother, but to do it voluntarily, out of the child's own free will. Such a false free choice is the obscene superego injunction: it deprives the child even of his inner freedom, ordering him not only what to do, but what to want to do (Žižek 2007, 93).

Med andre ord, selvom moderniteten i en vis forstand har medført et 'faderløst' samfund, sådan som det er blevet hævdet, betyder det på ingen måde, at 'faderen' er forsvundet, der er snarere tale om, at den traditionelle fader med hans officielle forbud og grænsedragninger er blevet afløst af en anden og mere subtil 'faderfigur', der virker gennem et obskønt incitament til overskridelse.

Ligesom Foucault mener Žižek altså, at det er gennem selve opfordringerne til frigørelse og nydelse, at vi mest effektivt underlægges magten i det moderne samfund. Men i modsætning til Foucault ser han ikke kristendommen og psykoanalysen som et led i, men snarere et skridt på vejen ud af denne ideologiske mekanismes onde cirkel. Ganske kortfattet kan man sige, at den grundlæggende uoverensstemmelse mellem Foucault og Žižek handler om, hvorvidt kristendommen gennem bekendelsen internaliserer en 'lovens dialektik', hvori forbuddet og overskridelsen gensidigt forstærker hinanden, som så senere videreføres i psykoanalysen; eller om kristendommen og senere psykoanalysen tværtimod i kraft af deres kritiske distance til de sociale fantasier, som opretholder denne dialektik, netop muliggør et brud med den (Žižek 1999, 152). ${ }^{22}$

22. Ifølge Žižek bunder hans uenighed med Foucault - herunder også hans uenighed med Foucaults kritik af psykoanalysen og kristendommen - i sidste ende i en modstand imod, hvad han anser for en 'pervers' cirkularitet imellem magtudøvelse og modstand i Foucaults magttænkning. I Žižeks optik udgør denne cirkularitet en teoretisk reproduktion af lov-dialektikkens ideologiske mekanisme, hvorved en ægte modstandsposition, et genuint brud med magten, bliver en umulighed. Se Slavoj Žižek, The Ticklish Subject: The Absent Centre of Political 


\section{Konklusion}

Hvis vi her afslutningsvis ganske kort skal vende tilbage til Nietzsche, så kan man opsummerende sige, at hans pointe i den indledningsvis citerede passage fra Moralens oprindelse er, at kristendommens vilje til sandhed er så stærk eller kompromisløs, at den til sidst vender sig imod sig selv, og således ender med at problematisere, ja på sin vis opløse, sin egen gudstro. Dette sidste skridt tages ifølge Nietzsche i kraft af den moderne filosofi og videnskab, der på paradoksal vis ikke alene har kristendommen som baggrund, men også kan siges netop at udgøre dens ophøjelse og overføring (Nietzsche 1998, 162). Det betyder imidlertid ikke, sådan som 'oplysningens fortalere' til tider ynder at hævde, at den kristne Guds død er historien om den moderne videnskabs og filosofis sejr. Nej, i Nietzsches perspektiv er der snarere tale om historien om eksekveringen af en uundgåelig dødsdom, som kristendommen selv indeholder kimen til, hvori den moderne videnskab og filosofi blot spiller rollen som bøddel. Denne historie, som ifølge Nietzsche tager sin begyndelse allerede hos Platon, og hvis afslutning altså står for døren med den kristne Guds død, er også den historie, som Nietzsche har givet navnet 'den europæiske nihilisme', hvilket netop vil sige historien om, hvordan 'de højeste værdier mister deres værdi'. 23

Žižek deler Nietzsches opfattelse af, at den moderne tids problematisering af kristendommens gudstro ikke alene er resultatet af en lang historisk proces, men at den allerede er til stede i udgangspunktet; dog ikke som hos Nietzsche i form af en nedarvet platonisk metafysik, men i form af Kristi råb på korset "Min Gud, min Gud, hvorfor har du forladt mig?". Med andre ord, for Žižek er kristendommens (bogstavelig talt) grundlæggende og glædelige budskab, at dens Gud allerede fra begyndelsen er en Gud, der vedgår sig sin egen død, hvilket i Žižeks perspektiv ikke er et udtryk for indvarslingen af en uundgåelig forfaldshistorie, men tværtimod for et muligt brud med metafysikken. I Žižeks ateistiske øjne er kun den Gud, der gør det, som synes at være en umulighed i enhver religion, nemlig lider og dør, en sand Gud, og i den forstand er den kristne Gud enestående og kristendommen en enestående religion, hvorfor Žižek også - i stil med Ernst Bloch - har givet kristendommen det paradoksale prædikat

Ontology (London: Verso 1999), 251-254. Gilles Deleuze har påpeget en lignende 'cirkularitet' i Foucaults magttænkning i 1970'erne. Se Gilles Deleuze, Foucault (Frederiksberg: DET lille FORLAG 2004), 109-114.

23. Friedrich Nietzsche, Nachlaß 1885-1887 i: (red.) G. Colli og M. Montinari Sämtliche Werke Band 12, Kritische Studienausgabe (München: Deutscher Taschenbuch Verlag, de Gruyter 1980), 211-217 og 350. 
'ateismens religion' (Žižek 2003, 171). Der er således ikke tale om 'vending imod religionen' hos Žižek, da han på ingen måde er ude efter at rehabilitere religionen som sådan. Tværtimod forsøger han i kristendommen netop at finde ressourcer til at kritisere og bekæmpe samtidens religiøsitet, hvad enten det er i form af New Age eller i form af den religiøse kerne, der overlever i forskellige humanistiske og sekulære erstatninger for den store Anden som garant for livets mening. Det er på denne metafysik- og religionskritiske baggrund, man skal forstå hans tale om kristendommen som 'ateismens religion':

The point of Christianity as the religion of atheism is not the vulgar humanist one that the becoming-man-of-God reveals that man is the secret of God (Feuerbach et al.); rather, it attacks the religious hard core that survives even in humanism, even up to Stalinism, with its believe in History as the "big Other" that decides on the objective meaning of our deeds (Žižek 2003, 171).24

Også Nietzsche har blik for, at kristendommens Gud er en lidende og døende Gud og som sådan enestående. ${ }^{25}$ Men i modsætning til Žižek er en Gud, der kan lide og dø, i Nietzsches øjne slet ikke nogen Gud, men selve gudsbegrebets negation. Som han skriver i Antikrist: "[...] deus, qualem Paulus creavit, dei negatio" (Nietzsche 1994, 63). Det er præcis dette forhold, som Žižek fremhæver som kristendommens (metafysik)kritiske potentiale, nemlig at Gud her tænkes som lidende, ja døende, der får Nietzsche til at afvise den kristne Gud. Det har fået Eberhard Jüngel, som ellers netop gør en dyd ud af at understrege Nietzsches teologiske finfølelse, til at anklage ham for en 'anti-teologisk snæversynethed', der i sidste ender betyder, at han på trods af sin heftige kritik af metafysikken alligevel forbliver inden for dennes rammer, i hvert fald når det gælder gudstanken. ${ }^{26}$

24. Žižek illustrerer også den væsentlige forskel mellem en humanistisk og en kristen ateisme på følgende vis: "In the standard form of atheism, God dies for men who stop believing in Him; in Christianity, God dies for Himself" (Žižek 2003, 15).

25. Friedrich Nietzsche, Antikrist: Forbandelse over Kristendommen (København: Hans Reitzels Forlag 1994), 68-69.

26. Med Jüngels ord: "Darin blieb auch Nietzsche im Gegenüber zur Metaphysik zutiefst der Metaphysik verhaftet: daß er das Vergängliche ohne den Schmerz, daß er das Vergehen ohne das Leid und ohne die Trauer des Abschieds gedacht wissen wollte und daß er deshalb die Verehrung eines leidenedes Gottes 'Verbrechen am Leben' anklagen mußte”, Eberhard Jüngel, Gott als Geheimnis der Welt: Zur Begründung der Theologie des Gekreuzigten im Streit zwischen Theismus und Atheismus (Tûbingen: Mohr Siebeck 2001), 281. For en videre udfoldelse af konteksten for og de teologiske konsekvenser af Jüngels udlægning af Nietzsches 
I lyset af det ovenstående kan man opsummerende sige, at de indledningsvist citerede ord fra Johannesevangeliets om, at "I skal lære sandheden at kende og sandheden skal gøre jer frie" kan udlægges på to markant forskellige måder, som begge kan siges at fortælle os noget vigtigt om kristendommens sandhed og denne sandheds fortsatte aktualitet. På den ene side er der ingen tvivl om, som først Nietzsche og siden Foucault har vist, at hvis kristendommens sandhedsfordring alene består i kravet om en afsøgning og udsigelse af sandheden om os selv, så udgør den, snarere end en frigørelse, en subtil måde at knægte os på, og det sågar i selve det øjeblik, hvor vi selv forestiller os at være allermest frigjorte. På den anden side er der heller ingen tvivl om, som Žižek har vist, at hvis kristendommens sandhedsfordring derimod består i en opfordring til at være tro imod, eller 'true to', som det netop hedder på engelsk, dens traumatiske åbenbaring af, at Gud er død, så rummer kristendommen samtidig et genuint kritisk og frigørende potentiale. At gennemtænke de videre (teologiske) konsekvenser af Guds død med afsæt i, og om nødvendigt i opposition til, dens egen righoldige tradition er således (fortsat) en af den kristne teologis fornemste opgaver.

forståelse af Guds død, samt forbindelsen til Luthers kristologi og korsteologi, se Carsten Pallesen, "Ordet om Guds død i erfaringstopologisk perspektiv", Dansk Teologisk Tidsskrift 69 (2006), 161-183. 